\title{
Digital Technology and Quality Management
}

\author{
K K Ramachandran, K K Karthick
}

\begin{abstract}
The current study address to find out the scenario of digital technology and quality management. The papers explore the sectors for improvement of the existing and creation of new tools, techniques and quality management systems in the light of the development of digital technologies. Awareness about this technology in Chennai district of Tamilnadu. The principles are a set of underlying assumptions about how to view the organization and its relation to customers, competitors and suppliers. Quality management is based on three principles: customer focus, continuous improvement and teamwork. All organizations can have more or less systematic, integrated and proactive approaches to deal with the principles. Accordingly, a quality profile cannot simply be implemented on the basis of the existing management structures and systems. It may require the redesign of work, the redefinition of managerial roles, the redesign of organizational structures, the learning of new skills by employees and the reorientation of organizational goals

There are many places which are unaware about technology hence the researcher feels to study on the awareness of Digital Technology and Quality Management in the District of Chennai(Tamil-Nadu).
\end{abstract}

Keywords : Digital technology, Quality, Quality Management, Integrated, TQM,Indian awareness, sectors, Chennai, etc.

\section{INTRODUCTION}

Digital technology for quality management having three types those are interrelated.

1. There should be improvement in development processes with technology, such as new development tools or programming teams.

2. Involvement of IT with organisation for the development.

3. Innovations in which the uses of digital technology either in business functions or core processes of the organization.

These three types of development are mutually dependent, as an innovation in one type may lead to innovations in others. This co-dependency is created because digital technology processes are simultaneously before the study it is essential to know what are the aims and objectives of digital technology and quality management in India.

The main objectives of digital technology and quality management:

\footnotetext{
Revised Manuscript Received on July 22, 2019.

Dr. K K Ramachandran, Dr. K K Karthick,

Professor,GRD Institute of Management, Coimbatore

Professor, PMR Institute of Technology, CHENNAI
}

a. To improve the digitization involving with quality management procedures across the country in the country.

b. To minimize the efforts and improving the technology for organisation.

c. To replace a lot of other management process to reduce efforts of organisation

d. To comprehend with most of the quality management with digital technology.

e. To improve the effect of digital technology over the quality improvement of each and every area.

f. To improve the competitiveness of the organisation.

g. To ensure the availability of knowledge for the improvement

h. To reduce the complications in the system and organisation

i. To decrease the unhealthy competition among the states due to unawareness of digital technology..

j. To reducing the quality management problems to avoid further issues.

k. To simplify the process of quality management with effect of digital technology.

Thus, there are many good and beneficial aims and objectives of using digital technology for the quality management in India.

Chennai is one of the 33 districts of Tamil Nadu. There are six districts in the Northern Sector of Tamil Nadu. Chennai is the smallest city and one of the most dense and populated district. Current study aims to find out the awareness of sectors of Chennai District in Tamil Nadu.

\section{LITERATURE REVIEW}

There are several studies on digital technology and quality management in India. Few of them are highlighted as:

Digital Technology in the Realm of Banking was studied by Varda Sardana and Shubham Singhania (2018). In his study, he highlighted upon the objectives of digital technology in banking sector.

Another study was conducted by Harsh Bajpai (2018) the future of work in India. His study continued with the explanation of the features 
digital technology, effect of digital technology on quality management in different sector.

Digital technology has been analysed and compared with the proposed and current demand of organisation, by Prashant Kumar Panday (2018). He further described the plans on employment and various sectors.

Difference between digital technology on quality management and past situation has been studied by Nishad Nawaz (2017). They have highlighted upon the effect of digital technology after its implementation as well they mentioned challenges and benefits of digital technology in implementation over quality management in different field of India.

Gopal, Dr,Rajesh (2017) stated overview of quality management,system,standard for the development of different fields.

\section{AIMS AND OBJECTIVES OF THE STUDY}

a. To study about digital technology and quality management India

b. To study about the awareness of about digital technology and quality management the customers of Chennai District.

c. To study about the awareness of about digital technology and quality management amongst the customers of rural parts of Chennai District in Tamil Nadu.

\section{Hypothesis:}

a. There is not clear picture of about digital technology and quality management to the all sectors of Tamil Nadu.

b. Rural customers are not having proper knowledge of about digital technology and quality management.

\section{Methodology of the Study:}

Survey method with providing the questionnaire to the respondent is used for current study. Written and interview test are conducted for the organisation. Few schemes were also asked them.

\section{Limitation of the Study:}

Current study is limited with the Chennai District of Tamil Nadu. Hence no data is collected outside this district.

Sources of Data Collection:

Following two types of source is used for the data collection of current study.

a. Primary Source: For the current study the descriptive and experimental research method is used. The design of the study is adopted for doing this research paper. b. Secondary Source: Secondary source for current study is used from the books, journal, articles, thesis -both published and unpublished, available material on current study in printed form, even available on internet. The data for the study has been collected from secondary sources like newspapers, research papers and websites.

\section{Data Collection Method:}

In Chennai district there are total 3 zones. Out of which five sectors are selected for the current study. i.e. Pharma, IT, Banking, medical, and mechanical. Total 50 people were selected as a sample size from these five places i.e. 10 from each.

Data of North Chennai:

\begin{tabular}{|l|l|l|}
\hline $\begin{array}{l}\text { Sr. } \\
\text { no. }\end{array}$ & $\begin{array}{l}\text { Customers' } \\
\text { Awareness }\end{array}$ & $\begin{array}{l}\text { Digital } \\
\text { technology and } \\
\text { quality } \\
\text { management } \\
\text { Sectors }\end{array}$ \\
\hline 01 & $100 \%$ & IT \\
\hline 02 & $80 \%$ & Banking. \\
\hline 03 & $75 \%$ & Pharmaceutical \\
\hline 04 & $80 \%$ & Mechanical \\
\hline 05 & $50 \%$ & Medical \\
\hline
\end{tabular}

Table 1.1

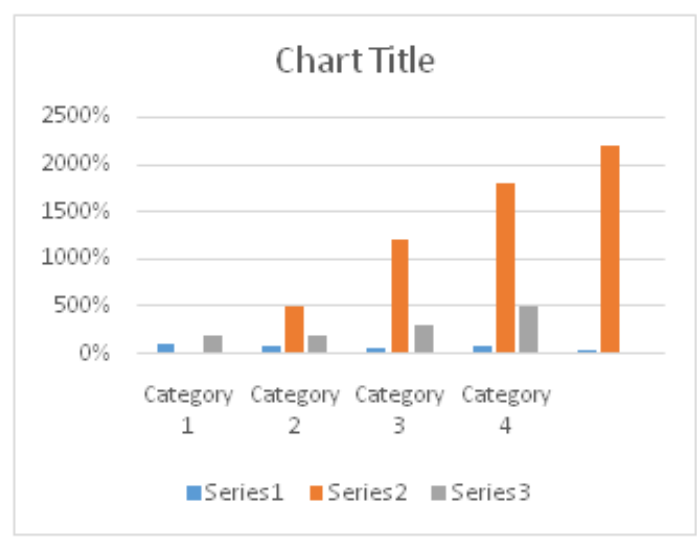

Graph 1.1

Data of Central Chennai:

\begin{tabular}{|l|l|l|}
\hline $\begin{array}{l}\text { Sr. } \\
\text { no. }\end{array}$ & $\begin{array}{l}\text { Customers' } \\
\text { Awareness }\end{array}$ & $\begin{array}{l}\text { Digital technology } \\
\text { and quality } \\
\text { management Sectors }\end{array}$ \\
\hline 01 & $90 \%$ & IT \\
\hline 02 & $80 \%$ & Banking. \\
\hline
\end{tabular}




\begin{tabular}{|l|l|l|}
\hline 03 & $85 \%$ & Pharmaceutical \\
\hline 04 & $60 \%$ & Mechanical \\
\hline 05 & $30 \%$ & Medical \\
\hline
\end{tabular}

Table 1.2

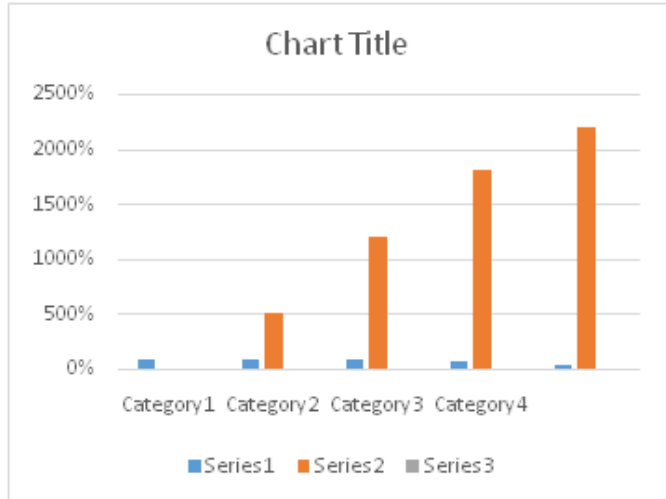

Graph 1.2

\section{Data of South chennai}

\begin{tabular}{|l|l|l|}
\hline $\begin{array}{l}\text { Sr } \\
\text { no } \\
\cdot\end{array}$ & $\begin{array}{l}\text { Customers } \\
\text { Awareness }\end{array}$ & GST Rate \\
\hline 01 & $100 \%$ & $\begin{array}{l}\text { Digital technology } \\
\text { and quality } \\
\text { management Sectors }\end{array}$ \\
\hline 02 & $90 \%$ & IT \\
\hline 03 & $80 \%$ & Banking. \\
\hline 04 & $70 \%$ & Pharmaceutical \\
\hline 05 & $50 \%$ & Mechanical \\
\hline
\end{tabular}

Table 1.3

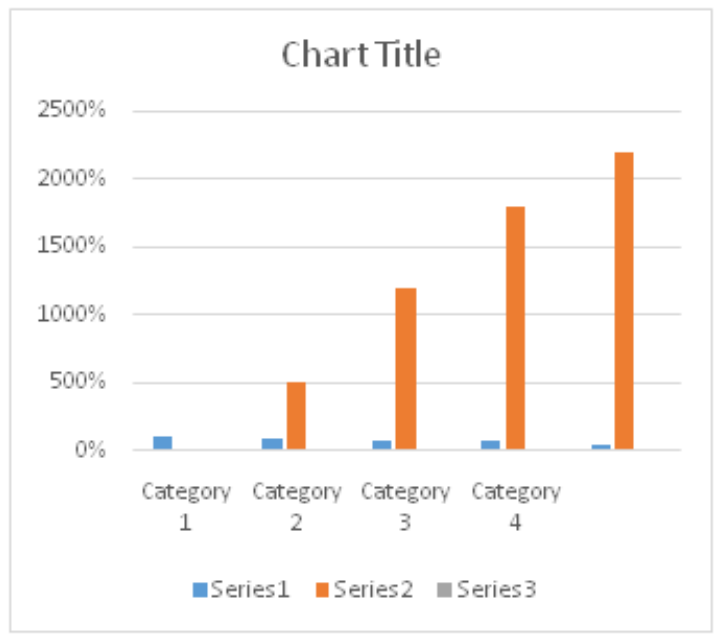

Graph 1.3

As shown in above tables and graph, most of the sectors are aware about digital technology and quality management in Chennai. They know on which sector digital technology and quality management is applicable and on which product it not but they know it about used in everyday life. They are not much more aware about the about digital technology and quality management system which are having high demand and fast innovative growth. They know only concept and few of them knows about it in details. Finding of the study are given below:

\section{FIndings OF THE STUdY:}

a. There are many cases in which client themselves are confused about digital technology and quality management and its applications and norms of it. Therefore, customers knew only that these are digitalized and these are under technology.

b. What is exactly digital technology and quality management and its applications very few of know.

c. As digital technology and quality management is new concept, it will take time to understand to the customers also in the point of view of its benefits.

d. It is not simple and easy to understand the concept of digital technology and quality management and its applications.

e. e. Overall study shows that early stage of digital technology and quality management supplication will be a part of creating complication in the mind of consumers.

f.There are negative approach and views of customers about digital technology and quality management and its applications.

g. Lack of IT facilities is also one of the major reasons to make consumers unaware about digital technology and quality management.

h. Suggestions of the Study:

i. It is essential to give training for practical knowledge of digital technology and quality management and its applications.

$\mathrm{j}$. Need of counselling and communicating to all level of sectors about digital technology and quality management and its applications and its benefits.

k. It is necessary to inform the customers that digital technology and quality management and its applications.is more advanced and innovative than previous technologies

1. It is essential to convey all the sectors to make aware that there is no exemption from digital technology and quality management to anyone, so they 
should prepare themselves with positive attitude towards the use of it.

m. It needs to go time to understand the particle benefits of digital technology and quality management and its applications to consumers

\section{CONCLUSION}

Thus, these is always problem when new approach or new method is introduced in any sector. Even it is experienced that there is no one who can understand any technology with fully desired expectation. Even not of those who are working in the professions such as Lawyers, Chartered Accountants, Company Secretaries, etc. if such scenario is there for any technology, how one can expect that digital technology at initial stage should be understood by common people who are the users of system which they require for their routine life. Digital technology and quality management to improvement will take time to understand. It is not as hard as to understand but to apply $\mathrm{n}$ organisation quickly. there were different ratio of previous system which were divided as per location of users. Such complications are not in the application of digital technology. As it is new, it will take some time to understand by the consumers about its system, pattern benefits and application. They will be aware about it when will start to use it by practically through. It needs only proper counselling.

\section{REFERENCES}

[1] “An Overview of Literature Review on ISO 9001 Standards ", 2017,Vol 9.

[2] "Review of digitization of ", March 2018,VOL 7.

[3] https://cleartax.in/s/all-about-gst-gov-in-gst-portal How Digital Transformation And Quality management Play Important Roles In Optimizing Your Business

[4] https://www.intellect.com/blog/how-digital-transformation-and-quality-m anagement-play-important-roles-in-optimizing-your-business

[5] International Review of Business and Finance ISSN 0976-5891 Volume 9, Number 1 (2017), pp. 31-34.

[6] "Information communication technology policy", Government of Tamilnadu,2018

[7] "Carlson, W. and McNurlin, B. (1992). "Basic principles for measuring IT value", I/S Analyzer, Vol. 30 No. 10, pp. 1-16.

[8] " Ahire, S.L. (1996). "TQM age versus quality: An empirical investigation", Production and Inventory Management Journal, First quarter, pp. 18-23.

[9] " A Case Study on Quality Management and Digital Innovation Relationship and Learning Aspects ", 2013 